
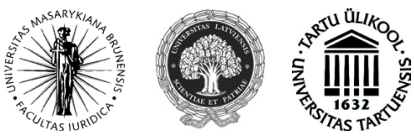

ISSN 1392-6195 (print) ISSN 2029-2058 (online) JURISPRUDENCIJA JURISPRUDENCE 2014, 21(2), p. 399-420.

\title{
SELECTED PROBLEMS OF IMPLEMENTATION OF THE ESPOO CONVENTION IN UKRAINE (ON THE EXAMPLE OF BYSTROE CANAL CASE)
}

\author{
Victoria Rachynska \\ Opole University, Faculty of Law and Administration \\ Katowicka street, 87a, 45060, Opole, Poland \\ Tel.: +48774527500 \\ E-mail: vikarachinskaya@gmail.com
}

Submitted on 17 February, 2014; accepted on 30 May, 2014

doi:10.13165/JUR-14-21-2-04

"The bravest sight in the world is to see a
great man struggling against adversity."

(Seneca)

\section{Introduction}

The impact of human activities on the environment has rapidly increased in the last two centuries, which has eventually aggravated health and living conditions of a wide population. Tremendous growth of production and consumption, irresponsible attitude towards the implementation of the latest achievements of technological advancement as well as the wide usage of outdated and hazardous equipment with the only aim of reaching the most possible profits pose a serious threat to further human well-being. Nowadays people are capable of influencing the lives of other people (who may be even hundreds of thousands of kilometers away from them) to a large degree. It seems to be equitable to entitle these likely to be affected people to express their opinion, to submit their comments and concerns regarding the proposed activity and to consider the received information while taking the final decision regarding this activity.

Jurisprudencija/Jurisprudence

(C) Mykolo Romerio universitetas, 2014

(C) Mykolas Romeris University, 2014
ISSN 1392-6195 (print), ISSN 2029-2058 (online) http://www.mruni.eu/lt/mokslo_darbai/jurisprudencija/ http://www.mruni.eu/en/mokslo_darbai/jurisprudencija/ 
The Espoo Convention provides an indispensable framework for international cooperation in assessing environmental impact, in particular in a transboundary context ${ }^{1}$. This Convention facilitates the realization of several principles stipulated by the Rio Declaration (including the states' obligation to provide prior and timely notification and relevant information to potentially affected states on activities that may have a significant adverse transboundary environmental effect and to consult with those states at an early stage and in good faith) ${ }^{2}$.

Ukraine ratified the Espoo Convention by adopting the Law of Ukraine "On ratification of the Convention on Environmental Impact Assessment in a Transboundary Context” № 534-XIV of 19.03.1999³. Under Article 9 of the Constitution of Ukraine, effective appropriately ratified international agreements constitute a part of the domestic legal order ${ }^{4}$. However, Ukraine fails to undertake the necessary legislative, regulatory and other measures to establish and maintain a clear, transparent and consistent framework to implement the provisions of the Espoo Convention. One of the striking examples of Ukraine's noncompliance with it is the Bystroe Canal Case.

Different general issues related to the compliance mechanism of the Espoo Convention and (less) the Aarhus Convention ${ }^{5}$ have been explored in specialized literature (including the analysis of distinct aspects of the Bystroe Canal Case) ${ }^{6}$. The

1 Espoo Convention on Environmental Impact Assessment in a Transboundary Context. February 25, 1991 (entered into force Sep. 10, 1997) [hereinafter Espoo Convention].

2 Rio Declaration on Environment and Development. In: Report of the United Nations Conference on the Human Environment. Stockholm, 5-16 June 1972 (United Nations publication, Sales No. E.73.II.A.14 and corrigendum), Chap. I [interactive]. [accessed on 0202-2014]. <http://www.un.org/documents/ga/conf151/aconf15126-1annex1.htm>.

3 Zakon Ukrainy "Pro Ratyfikatsiju Konvencii pro Ocinku Vplyvu na Navkolysnie Seredovyscie u Transkordonnomu Konteksti” № 534-XIV of 19.03.1999. Vidomosti Verhovnoj Rady Ukrainy. 1999, 34: 296.

4 Konstytucija Ukrainy of 28.06.1996 № 254K/96-BP [interactive]. [accessed on 02-02-2014]. $<$ http://zakon2.rada.gov.ua/laws/show/254\%D0\%BA/96-\%D0\%B2\%D1\%80>.

5 Aarhus Convention on Access to Information, Public Participation in Decision-making and Access to Justice in Environmental Matters. June 25, 1998, 38 I.L.M. 517 (entered into force Oct. 30, 2001) [hereinafter Aarhus Convention].

6 Bastmeijer, K., and Koivurova, T. (eds.). Theory and Practice of Transboundary Environmental Impact Assessment. Leiden/Boston: Brill/Martinus Nijhoff Publishers, 2008, p. 397 (regarding the inquiry procedure in the Bystroe Canal Case, see p. 46-47);

Schmeier, S. Governing International Watercourses: River Basin Organizations and the Sustainable Governance of Internationally Shared Rivers and Lakes. Routledge, 2012, p. 344 (for general description of the Bystroe Canal Case, see p. 209-211);

Boschiero, N.; Scovazzi, T.; Pitea, C., and Ragni, C. (eds.). International Courts and the Development of International Law: Essays in Honour of Tullio Treves. Springer, 2013, p. 990 (the Bystroe Canal Case is mentioned while analyzing the causes of non-compliance with the Espoo Convention, p. 176-177);

Fauchald, O.K.; Hunter, D., and Xi, W. (eds.). Yearbook of International Environmental Law; 
problems of Ukraine's implementation of the Espoo Convention have been explored in the papers of some researchers ${ }^{7}$. However, the issues of Ukraine's noncompliance with the Espoo Convention, in particular, with the aim to reveal its reasons, have not been a subject of a recent complex research. Therefore, this article aims to analyze problems of the implementation of the Espoo Convention in Ukraine and the approach of the Ukrainian government toward the compliance process under the Convention on the example of the Bystroe Canal Case, as well as the possible preconditions of these problems.

The used methodology includes comparative, logical and systematic and other methods.

\section{The general characteristic of the Espoo Convention and its Implementation Committee}

The Espoo Convention is regarded as "a key step to bringing together all stakeholders to prevent environmental damage before it occurs" ${ }^{\text {. }}$.

Volume 20, 2009. Oxford University Press, 2011, p. 229-231;

C.E. Science and the Precautionary Principle in International Courts and Tribunals: Expert Evidence, Burden of Proof and Finality..Cambridge University Press, 2011, p. 375 (in terms of the activity of the Inquiry Comission, see p. 161-162);

Kravchenko, S. The Aarhus Convention and Innovations in Compliance with Multilateral Environmental Agreements. Colorado Journal of International Environmental Law and Policy. 2007, 1 (18) [interactive]. [accessed on 02-02-2014]. <http://papers.ssrn.com/sol3/papers. cfm?abstract_id=1076746>;

Handl, G.; Zekoll, J., and Zumbansen, P. (eds.). Beyond Territoriality: Transnational Legal Authority in an Age of Globalization. Martinus Nijhoff Publishers, 2012, p. 566 (in terms of the activity of the Inquiry Commission, see p. 187);

Jendrośka, J. Practice and Relevant Cases that Emerged in the Context of the Espoo Convention Implementation Committee. In: Non-Compliance Procedures and Mechanisms and the Effectiveness of International Environmental Agreements. The Hague: T.M.C.ASSER PRESS,,2009, p. 328-331 [interactive]. [accessed on 02-02-2014]. <http://air.unimi.it/ bitstream/2434/57918/2/treves_240109.pdf>;

Alekseyeva, Y. Once Again about the Aarhus Convention and Ukraine's Failure to Comply with its Obligation. Environment People Law Journal. 2011, 9-10 (49-50): 9-12 [interactive]. [accessed on 02-02-2014]. <http://epl.org.ua/uploads/media/EPL_2011_09_10_web_01.pdf>.

7 Melen', O. Dunajs'ka Sprava Tryvaje. Visnyk Ekologicnoji Advokatury. 2005, 28-29: 40-41 [interactive]. [accessed on 02-02-2014]. <http://epl.org.ua/uploads/media/V28-29.pdf>; Melen', O. Kanal Dunaj-Chorne More - Nevyriseni Pytannia. Visnyk Ekologicnoji Advokatury. 2006, 30: 21-23 [interactive]. [accessed on 02-02-2014]. <http://epl.org.ua/uploads/media/ V30.pdf $>$.

8 Introduction to Espoo Convention from the Convention's website [interactive]. [accessed on 02-02-2014]. <http://www.unece.org/env/eia/welcome.html>.

Andrusevych, A. Ukraine's Compliance with its Obligations under the Convention on Access to Information, Public Participation in Decision Making and Access to Justice in Environmental Matters. Environment People Law Journal. 2006, 31: 9-14 [interactive]. [accessed on 02-022014]. <http://epl.org.ua/uploads/media/V31.pdf>. 
The Espoo Convention sets out the obligations of Parties to assess the environmental impact of activities that are likely to cause a significant adverse transboundary impact on the environment. It also lays down the general obligation of States to notify and consult each other on all such activities at an early stage of planning. The Espoo Convention provides for ten mandatory steps and one voluntary step for its Parties to undertake before the activity that is likely to have a significant adverse environmental impact across boundaries is authorized.

Mandatory steps include the following ones: the necessary legal, administrative or other measures to implement the provisions of the Espoo Convention (Art. 2, para. 2, 5 of the Espoo Convention); notification (Art. 3, para. 1); confirmation of participation (Art. 3, para. 3); transmittal of information (Art. 3, para. 6); public participation (Art. 3, para. 8); preparation of EIA documentation (Art. 4); distribution of the EIA documentation for the purpose of participation of authorities and public of the affected country (Art. 4, para. 2); consultation between Parties (Art. 5); final decision (Art. 6, para. 1); transmittal of final decision documentation (Art. 6, para. 2).

The voluntary step is post-project analysis (Art. 7, para. 1).

In 2001, in order to assist Parties in complying with their obligations under the Espoo Convention, the Meeting of the Parties to the Convention established an Implementation Committee "for the review of compliance by the Parties with their obligations under the Convention with a view to assisting them fully to meet their commitments". The Implementation Committee usually meets at least once a year and consists of eight members appointed by eight Parties to the Espoo Convention. These Parties are reelected at each Meeting of the Parties ${ }^{10}$.

The main Implementation Committee's function is to consider submissions made by one or more Parties to the Espoo Convention regarding non-compliance by a Party with its obligations. The Implementation Committee reports on its activities at each meeting of the Parties ${ }^{11}$.

If the Committee provisionally finds that the Party which compliance is in question is not in compliance, it should then consider and agree upon possible recommendations to the Meeting of the Parties, recalling that the present compliance procedure is non-adversarial and assistance-orientated. Possible recommendations to bring about compliance might include the following: recommendations to the Party

Regarding the possibility of "public trigger" (allowing the public to formally initiate the compliance procedure) under the Espoo Convention compliance mechanism and other features of the mechanism, see: Jendrośka, J. Practice and Relevant Cases., p. 328-331.

9 ECE/MP.EIA/4, decision II/4 [interactive]. [accessed on 02-02-2014]. <http://www.unece.org/ fileadmin/DAM/env/documents/2001/eia/decision.II.4.e.pdf>.

10 Ibid., Annex IV, para. 1, 2.

11 ECE/MP.EIA/4, decision II/4, Annex IV, para. 4, 9 [interactive]. [accessed on 02-02-2014]. $<$ http://www.unece.org/fileadmin/DAM/env/documents/2001/eia/decision.II.4.e.pdf $>$. 
concerned on what legislation, procedures or institutions require strengthening and how; recommendation to the Party concerned to submit to the Committee a strategy, with time schedule, for action to bring about compliance, and to report to the Committee on its implementation of the strategy; recommendation to the Meeting of the Parties to issue a declaration of non-compliance or a caution; (in exceptional circumstances) recommendation to the Meeting of the Parties to suspend, in accordance with the applicable rules of international law concerning the suspension of the operation of a treaty, the special rights and privileges accorded to the Party concerned under the Espoo Convention.

The operating rules of the Implementation Committee were established by the Meeting of the Parties in the Annex IV to Decision IV $/ 2^{12}$, amended by Decision $\mathrm{V} / 4^{13}$.

Thus, the Implementation Committee is a special body to deal with reviewing compliance in non-adversarial and assistance-oriented non-compliance procedure of the Espoo Convention. A similar body was created under the Aarhus Convention and it was called the Compliance Committee.

It should be mentioned that the opinion of "the affected Party" is not binding for "the Party of origin" when taking the final decision. In opinion of the Implementation Committee, "initiation of the transboundary procedure under the Convention does not prevent the Party of origin from undertaking such proposed activities after having carried out the transboundary procedure, provided that due account is taken of the transboundary procedure's outcome in the final decision (art. 6, para. 1)"14.

The first breach of the Espoo Convention that was submitted to the Implementation Committee was the Bystroe Canal Case. This case was precedential because it brought to light a number of important legal issues, and it was a chance to examine the established compliance procedure.

12 Operating Rules of the Implementation Committee. Decision IV/2 of the Meeting of the Parties, doc. ECE/MP.EIA/10, p. 116 [interactive]. [accessed on 02-02-2014]. <http://www.unece.org/ fileadmin/DAM/env/eia/documents/ImplementationCommittee/IC_operatingrules_en.pdf $>$.

13 Amendment of the Operating Rules of the Implementation Committee. Decision V/4 of the Meeting of the Parties on Review of Compliance, doc. ECE/MP.EIA/15, Annex [interactive]. [accessed on 02-02-2014]. <http://www.unece.org/fileadmin/DAM/env/documents/2011/eia/ decision.V.4.e.pdf>.

14 Decision IV/2, Annex I, para. 55 [interactive]. [accessed on 02-02-2014]. <http://www.unece. org/fileadmin/DAM/env/documents/2008/eia/ece.mp.eia.10.e.pdf>;

Findings and Recommendations Further to a Submission by Romania Regarding Ukraine (EIA/IC/S/1) [interactive]. [accessed on 02-02-2014]. <http://www.unece.org/fileadmin/ DAM/env/documents/2008/eia/ece.mp.eia.2008.6.e.pdf>. 


\section{Investigation under the Espoo Convention of the Bystroe Canal Case}

\subsection{The subject and Parties of the Case}

The Bystroe Canal Case ${ }^{15}$ between Romania (the affected Party) and Ukraine (the Party of origin) concerns the project "The Danube-Black Sea Deep-Water Navigation Canal in the Ukrainian Sector of the Danube Delta"16. This navigation canal joins the Danube (the river that flows in Ukraine and in Romania as well) with the Black Sea. The canal existed before, but it needed some renovation in order to be used again.

The project fell under the scope of Article $1(\mathrm{~V})^{17}$ and of item 9 in Appendix I to the Espoo Convention ("inland waterways and ports for inland-waterway traffic which permit the passage of vessels of over 1,350 tones"). Thus, the project was subject to the Espoo Convention.

The project was divided into two separate phases: Phase I and Phase II, each subject to the different state ecological examination procedure ("ekologichna ekspertyza"). This procedure was called in the documents of the Compliance Committee of the Aarhus Convention in different ways ("environmental expertisa", "state environmental review" or "ecological expertise"). However, its explanation of this mechanism should be mentioned there: "it is an evaluation and, where appropriate, approval of the EIA by an authorized public authority"18, "formally established in the former Soviet Union in the second half of the $1980 \mathrm{~s}^{\prime \prime}$.

15 Case EIA/IC/S/1 bis - Romania vs. Ukraine [interactive]. [accessed on 02-02-2014]. <http:// www.unece.org/env/eia/implementation/eia_ic_s_1.html>.

16 Interesting perception of this matter is presented in the literature in the context of the Ukrainian-Romanian bilateral relations. According to it, the reason for the submission made by Romania can be a desire to avoid competition to its own transport routes - Sulina and St. George Channels; and "ecological slogans" may become merely tools in the competition for the exploitation of transport capacity of the Danube Delta (Iwański, T. Ukraina - Rumunia: przedłużający się impas. In: Karpia, M. Komentarze ośrodka studiów wschodnich im. № 68, 29.12.2011 [interactive]. [accessed on 02-02-2014]. <http://www.osw.waw.pl/sites/default/ files/komentarze_68.pdf > . It does not change the fact that Ukraine violated the Espoo Convention in this case.

17 "Proposed activity" means any activity or any major change to an activity subject to a decision of a competent authority in accordance with an applicable national procedure.

18 Report of the Compliance Committee of the Aarhus Convention on Its Seventh Meeting. Addendum, p. 3 [interactive]. [accessed on 02-02-2014]. <http://www.unece.org/fileadmin/ DAM/env/pp/compliance/S2004-01/S01C03findings.pdf $>$.

19 Report of the Compliance Committee of the Aarhus Convention on Its Thirty-first Meeting. Addendum, p. 5 [interactive]. [accessed on 02-02-2014]. <http://www.unece.org/fileadmin/ DAM/env/pp/compliance/CC-31/ece_mp.pp_c.1_2011_2_add.9_adv\%20edited.pdf>. 


\subsection{Facts and Legal basis}

\subsubsection{Authorization of the Phase I}

The procedure for authorizing Phase I was initiated in 2002. The Government of Ukraine notified Romania about the project without fulfilling all the requirements of the Espoo Convention. The final decision was taken in April 2004 and the works were initiated the following month.

The Government of Ukraine provided Romania with the environmental impact assessment documentation (the EIA report) concerning Phase I only on 5 August 2004 - a couple of months after the final decision was taken and works began, while the report should have been the basis of the bilateral consultations concerning the potential transboundary impact of the proposed activity and measures to reduce or eliminate its impact. Obviously, these consultations should have taken place before the final decision was taken.

In spite of the fact that the Government of Romania had contacted the Government of Ukraine several times requesting to be properly notified and involved in the transboundary procedure as envisaged in the Convention, Ukraine did not fulfill all the necessary procedures.

Before receiving the EIA report, but after the implementation of the Phase I started, on 26 May 2004, Romania made a submission about the case to the Implementation Committee.

As Ukraine denied that the project was likely to have a significant adverse transboundary impact on the environment, which would mean that the Espoo Convention should not be applied in this case, Romania wanted an inquiry commission to be established to investigate the case and to find an answer to the question whether the project could have such an impact or not.

The final opinion of the Inquiry Commission, in accordance with Article 3, paragraph 7 of the Convention, was that the project was likely to have a significant adverse transboundary impact. In such a situation, the requirements of the Espoo Convention did apply to the project and the opinion of the Implementation Committee was that Romania should be considered as the "affected Party" ${ }^{20}$.

An important legal issue arose during the investigations related to the legal effect of the opinion of the Inquiry Commission. The Implementation Committee considered that this opinion should have suspension effect, i.e., the implementation of the decision taken shall be stopped until the opinion of the Inquiry Commission was issued. The Implementation Committee also reached the conclusion that this opinion should be binding from the moment of adoption and it did not have retrospective effect, which meant that the decision on the Bystroe Canal project was invalid after

20 Findings and recommendations further to a submission by Romania regarding Ukraine... Regarding the legal status of the decision of the Inquiry Commission, see: Jendrośka, J. Practice and Relevant Cases..., p. 333-334. 
Ukraine was informed about the opinion of the Inquiry Commission. Thus, Ukraine should notify Romania and take other necessary measures in accordance with the Espoo Convention.

However, at this stage of the findings, Ukraine limited to expressing assurances that "the entire project would be conducted in line with relevant international obligations, which did not take place before the opinion of the Inquiry Commission was adopted because Ukraine did not think that the project was likely to have a significant adverse transboundary impact". In the next year, in a letter to the Executive Secretary of the UNECE, received on 30 May 2007, Ukraine stated that it was "studying further the issues raised in the final opinion of the Inquiry Commission" while continuing the realization of the Phase I.

Regarding this issue, the Implementation Committee took a note that the Espoo Convention does not provide for the Parties any opportunity to "study" an opinion of an inquiry commission, on the contrary, it requires notification to take place as early as possible and no later than when informing the public of the Party of origin. If the public of the Party of origin has already been informed about the proposed activity, the notification should be sent immediately ${ }^{21}$.

\subsubsection{Authorization of the Phase II}

Meanwhile, in 2004, Ukraine started to design the Phase II. The EIA report was finished in 2006. The report denied a significant adverse transboundary impact and failed to meet some other requirements of the Espoo Convention.

A formal notification was submitted to Romania only on 24 April 2007, more than 10 months after the final opinion of the Inquiry Commission was delivered. Furthermore, the notification failed to meet the requirements of the Espoo Convention by not mentioning "the nature of the possible decision" (as required by Art. 3, para. 2 of the Espoo Convention).

The EIA report was submitted to Romania even later. Romania and its public were not asked to deliver their comments, no consultations between Ukraine and Romania took place.

The precise date of the authorization of the Phase II varies in communications from the Government of Ukraine (19 April 2006 and 26 October 2006). Romania supposed that the final decision was the approval of the Phase II given by the Cabinet of Ministers of Ukraine (30 May 2007). In the end, Ukraine provided the final decision taken on 28 December, 2007 to the Government of Romania. However, as stated by a press release of the Ministry of Transport of Ukraine, the official opening of the canal was celebrated on 2 May, 2007 (!).

21 Report of the Fourth Meeting of the Parties (ECE/MP.EIA/10), para. 43 [interactive]. [accessed on 02-02-2014]. <http://www.unece.org/fileadmin/DAM/env/documents/2008/eia/ece.mp.eia. 10.e.pdf $>$. 


\subsection{Findings}

\subsubsection{In relation to the Phase I of the project}

The Meeting of the Parties, the fourth session (Bucharest, 19-21 May, 2008), stated that the fact of authorizing and implementing the Phase I could not be considered as being in clear non-compliance with the Espoo Convention at the time of the decision-making, because Ukraine thought that the project was not likely to have a significant adverse transboundary impact.

However, as Ukraine continued the implementation of the project after the matter had been submitted to the inquiry procedure and without carrying out the transboundary procedure, the Implementation Committee was of the opinion that, by doing so, Ukraine ignored the object and purpose of the inquiry procedure. That "made its obligation to prevent significant adverse transboundary environmental impact of the Phase I of the project impossible to achieve".

The Implementation Committee also found that not notifying Romania immediately after receiving the final opinion of the Inquiry Commission should be considered as non-compliance with the Convention.

Hence, Ukraine did not follow the requirements of the Espoo Convention to assure the proper involvement of the Romanian authorities and public in the respective EIA procedures. In particular, Ukraine did not notify Romania as envisaged in Art. 3, para. 2 of the Espoo Convention; did not submit information as envisaged in Art. 3, para. 5(a); did not take steps to ensure, together with Romania that the Romanian public in the areas likely to be affected was informed and provided with possibilities for making comments, as required under Art. 3, para. 8; did not furnish, as envisaged in Art. 4, para. 2 and Art. 2, para. 3, the EIA documentation to Romania before the decision was taken; did not take steps to arrange, together with Romania, for the distribution of the EIA documentation to the Romanian public, as required under Art. 4, para. 2; did not enter into consultations with Romania concerning the potential transboundary impact and measures to reduce or eliminate such impact, as required under Art. 5, and did not take steps to agree with Romania on a time frame for such consultations, as also required under Art. 5; did not ensure that the final decision authorizing implementation of the Phase I had taken into account the outcome of the consultations with Romania, as required under Art. 6, para. 1; did not provide Romania with the text of the final decision authorizing implementation of the Phase I, along with the reasons and considerations on which it was based, as required under Art. 6, para. $2^{22}$. on 02-02-2014]. <http://www.unece.org/fileadmin/DAM/env/documents/2008/eia/ece.mp.eia. 10.e.pdf $>$. 


\subsubsection{In relation to the Phase II of the project}

As the Phase II of the project was not finished at the moment of the submission, an important legal question that arose during the investigations was whether the Implementation Committee should accept submissions concerning pending projects or rather should wait with its findings until the project in question has been finalized. Taking into consideration the preventive role of the Espoo Convention, one can agree that such submission should be accepted. However, according to the Meeting of the Parties, as the final decision had not been taken, Ukraine could not be considered as not meeting the requirements of the Espoo Convention. A similar situation is in the case of Armenia that cannot be considered as being in non-compliance with the Espoo Convention because the final decision on the construction of the nuclear power plant was not yet taken and the works were not yet initiated, thus, there was still a possibility for Armenia to continue the implementation of the subsequent steps in the transboundary EIA procedure ${ }^{23}$.

The Implementation Committee hold the opposite opinion and found that, by failing to timely and sufficiently notify Romania after the final opinion of the Inquiry Commission, Ukraine was not in compliance with its obligations under Art. 3 of the Espoo Convention ${ }^{24}$. Nevertheless, as it was mentioned above, the Meeting of the Parties, the fourth session, stated that Ukraine could not be considered as being in noncompliance with the Espoo Convention as long as the final decision regarding the Phase II was not taken; and as long as before the final decision regarding the Phase II was taken all the necessary steps envisaged by the Espoo Convention had been followed ${ }^{25}$. Later, the Meeting of the Parties, the fifth session, stated that "while Ukraine had fulfilled some of its obligations under paragraph 10 of decision IV/2 $2^{26}$ with respect to both phases of the Bystroe Canal Project, it had not fulfilled all of these obligations"27.

23 Draft Decision VI by the Meeting of the Parties to the Convention, para. 46 [interactive]. [accessed on 02-02-2014]. <http://www.unece.org/fileadmin/DAM/env/documents/2014/ EIA/MOP/ECE.MP.EIA.2014.L.1.adcopy.pdf>.

24 Ibid., para. 65.

25 Ibid., para. 70.

26 The Fourth Meeting of the Parties "decided to issue a caution to the Government of Ukraine to become effective on 31 October 2008 unless the Government of Ukraine stopped the works, repealed the final decision and took steps to comply with the relevant provisions of the Convention".

27 Report by the Meeting of the Parties at Its Fifth Session (ECE/MP.EIA/15), Decision V/4 [interactive]. [accessed on 02-02-2014]. <http://www.unece.org/fileadmin/DAM/env/ documents/2011/eia/decision.V.4.e.pdf>. 


\subsection{Recommendations}

The Implementation Committee considered that Ukraine's national regulatory framework for authorizations of projects and the EIA seemed to be extremely complicated. In particular (as it was mentioned above), it was difficult to identify which of a number of consecutive decision-making procedures should be considered as the final "decision to authorize a proposed activity", as stipulated in Art. 2, para. 3 of the Espoo Convention. Moreover, there seemed to be no clear legal framework for transboundary EIA procedures. Thus, Ukraine did not comply fully with Art. 2, para. 2 of the Espoo Convention.

The provision of the Constitution of Ukraine to directly apply international agreements was considered by the Implementation Committee as being insufficient for proper implementation of the Espoo Convention without more detailed provisions in the legislation. In particular, the national regulatory framework should clearly indicate two issues. The first one is which of the decisions for approving the activities should be considered the final decision for the purpose of satisfying the requirements of the Espoo Convention. The second one is where in the decisionmaking process there is a place for a transboundary EIA procedure and who is responsible for carrying it out and by which means.

The Meeting of the Parties, fourth session, issued a declaration of non-compliance to the Government of Ukraine and a caution to become effective on 31 October, 2008 unless the Government of Ukraine stops the works, repeals the final decision and takes steps to comply with the relevant provisions of the Espoo Convention. It also requested Ukraine to adopt a strategy on implementation of the Espoo Convention into Ukrainian legislation; to adopt new laws that satisfy the Espoo Convention; as well as to negotiate with the neighbouring Parties about cooperation according to the Espoo Convention.

Ukraine met the last requirement. Some measures regarding the Phase II (not Phase I!) were also undertaken ${ }^{28}$. Namely, Ukraine repealed the final decision; notified Romania and sent the EIA documentation on the project to it; participated at a public consultation meeting in Romania on 9 June, 2009; organized a meeting with Romania in Kyiv on 15-16 July, 2009, where the comments to the project were discussed. However, works regarding the both phases were continued (even though no final decision on the Phase II was in force!). Although, Ukraine adopted the strategy to implement the Convention, recent changes in the legislation on the development control have not satisfied the strategy. Namely, the Ukrainian law № 
3830-VI of 17 February 2011 “On Regulating Urban Planning” introduced changes into the Ukrainian legislation "On Environmental Protection" and "On Ecological Expertise", which withdrew the IEA of the construction projects. The Chair of the Implementation Committee in his letter to Ukraine (dated 1 February 2011) posed questions regarding the strategy $y^{29}$. As there was no clarifying answer, the Chair of the Implementation Committee addressed his next letter regarding the same issue to the

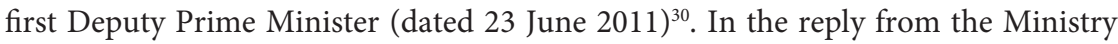
of Ecology and Natural Resources of Ukraine (Ministry of Natural Resources) to the Implementation Committee regarding the legislative changes, the Ministry did not explain the situation, but merely stated that it asked the Ministry of Regional Development, Construction, Housing and Public Utilities of Ukraine about the changes $(!)^{31}$.

The Meeting of the Parties, fifth session, acknowledged that Ukraine had fulfilled some of its obligations according to Decision IV/2 with respect to both phases of the Bystroe Canal Project, but not all of them ${ }^{32}$. Thus, the caution to the Government of Ukraine remained effective. The Meeting of the Parties also requested Ukraine to report each year on steps taken to bring into full compliance the Bystroe Canal Project with the Convention and on the implementation of the strategy, in particular on concrete legislative measures adopted to this effect.

In the next letter to Ukraine (dated 7 September 2011) the Chair of the Implementation Committee asked for further clarifications ${ }^{33}$. In following responses,

29 The letter is available at the Convention's website [interactive]. [accessed on 02-02-2014]. $<$ http://www.unece.org/fileadmin/DAM/env/eia/documents/ImplementationCommittee/eia. ic.s/eia.ic.s.1/Letter_to_Ukraine_inquiry_re_new_laws_1_Feb_2011_re_.pdf >.

30 The letter is available at the Convention's website [interactive]. [accessed on 02-02-2014]. $<$ http://www.unece.org/fileadmin/DAM/env/eia/documents/ImplementationCommittee/eia. ic.s/eia.ic.s.1/Ukraine_DPM_-_23_June_2011.pdf $>$.

31 The letter dated 10.06.2011 (received on 19.07.2011) is available at the Convention's website [interactive]. [accessed on 02-02-2014]. <http://www.unece.org/fileadmin/DAM/env/eia/ documents/ImplementationCommittee/eia.ic.s/eia.ic.s.1/Reply_by_Ukraine__19.07.11_-_ Unofficial_Translation.pdf $>$.

It should be also mentioned that this letter was dated 10.06 .2011 and received only on 19.07.2011. Taking into account that the letter of Chair of the Committee was dated 23.06.2011, as well as that even a bigger gap between "writing" the letter and its receiving (dated 01.08.2013 but received by the secretariat on 14.11.2013 (!)), it can be supposed that not only it is not true, but also Ukrainian officials do not care about the fact that it is obvious.

The latter information is available at the Aarhus Convention's website [interactive]. [accessed on 02-02-2014]. <http://www.unece.org/environmental-policy/treaties/public-participation/ aarhus-convention/envpptfwg/envppcc/envppccimplementation/fourth-meeting-of-theparties-2011/ukraine-decision-iv9h.html>.

32 Report by the Meeting of the Parties at Its Fifth Session..., para. 17.

33 The letter to Ukraine, dated 7 September 2011, is available at the Convention's website [interactive]. [accessed on 02-02-2014]. <http://www.unece.org/fileadmin/DAM/env/eia/ documents/ImplementationCommittee/eia.ic.s/eia.ic.s.1/Letter_to_Ukraine_7.9.11.pdf>. 
Ukraine tried to provide the Implementation Committee with some information on the posed questions as well as with progress reports as requested by the Meeting of the Parties at its fifth session (Decision V/4, para. 24) ${ }^{34}$, however, as mentioned at the Espoo Convention's website, no apt steps to implement the Convention were taken.

These issues are going to be considered at the next, sixth, session of the Meeting of the Parties to the Espoo Convention, from 2 to 5 June, 2014.

\section{General analysis of the situation and its supposed prerequisites}

It is easy to notice that compliance with the Espoo Convention by the Ukrainian government was limited to promising and pretending that it was doing so. The final decision on the Phase II was repealed while the implementation of works was continued; the questions posed by the Implementation Committee were often ignored; legislature contradicting to the Espoo Convention was adopted, etc. Unfortunately, frequent infringement of Ukraine's international obligations by Ukrainian governmental bodies noticed by a number of scholars ${ }^{35}$ shows the low importance attached to these obligations. What are the causes of such a situation?

For explanation of compliance behavior, four variables might be important: characteristics of the activities involved; characteristics of the accord; the international environment; factors involving the country ${ }^{36}$.

Undoubtedly, all these factors are important and affect the final result. The practice of the Implementation Committee also shows that many Parties have

34 Curiously, in this letter (received 7 September 2011) the Ministry of ecology and natural resources of Ukraine thanked the Implementation Committee of the Espoo Convention "for the fruitful cooperation". Taking into account that covering a lot of paper with ineffective writing cannot be considered as "an important fruit" in terms of environmental protection, what fruits it meant remains a mystery.

This letter from Ukraine is available at the Convention's website [interactive]. [accessed on 02-02-2014]. <http://www.unece.org/fileadmin/DAM/env/eia/documents/Implementation Committee/eia.ic.s/eia.ic.s.1/Unofficial_translation.pdf>.

Progress report by Ukraine of 29 December 2011 is available at the Convention's website [interactive]. [accessed on 02-02-2014]. <http://www.unece.org/fileadmin/DAM/env/eia/ documents/ImplementationCommittee/eia.ic.s/eia.ic.s.1/Report_Ukraine_2011_eng_ correctAppendix2.pdf $>$.

Progress report by Ukraine of 31 December 2012 is available at the Convention's website [interactive]. [accessed on 02-02-2014]. <http://www.unece.org/fileadmin/DAM/env/eia/ documents/ImplementationCommittee/eia.ic.s/eia.ic.s.1/Report_by_Ukraine_31.12.2012_ ENG.pdf $>$.

35 The Aarhus Convention and Innovations in Compliance..., p. 46. Andrusevych, A. Ukraine's Compliance with Its Obligations..., p. 9-14.

36 Jacobson, H.K., and Weiss, E.B. Assessing the Record and Designing Strategies to Engage Countries. In: Weiss, E.B., and Jacobson, H.K. (eds.). Engaging Countries: Strengthening Compliance with International Environmental Accords. MIT Press, 2000, p. 520. 
some problems in the implementation of the Espoo Convention. For example, the upcoming meeting of the Parties is going to consider the issues of noncompliance by Belarus with its obligations under the Espoo Convention with respect to the planned building of a nuclear power plant in Ostrovets ${ }^{37}$.

Nevertheless, it is Ukraine that is one of the most persistent violators of the obligations under the Espoo Convention. Therefore, this study does not cover all of these factors affecting the degree of compliance with international treaties. It covers only the most specific of them, namely, factors involving the country.

Among such factors, one can mention the goals and interests of the state, the level of democracy, economic development and territorial structure. The latter factor does not seem to be important in the case of Ukraine, as it is a unitary state. It is a federal state that has more difficulties in the implementation of international agreements ${ }^{38}$.

As for the level of democracy and economic development, it should be admitted that Ukraine does have problems in this area, which is also emphasized by researchers ${ }^{39}$.

Obviously, the probability of compliance is greater in countries with a larger gross domestic product (GDP), with a higher per capita GDP, and with a higher rate of economic growth ${ }^{40}$. That is, richer countries are more likely to comply with treaties than poor countries. Ukraine's economy is in transition from past socialist economies to some forms of capitalism. Economic growth is rather slow, and it certainly is not rich. Thus, Ukraine has economic problems and lacks financial resources to comply with treaties, as it emphasizes at international meetings ${ }^{41}$.

There are many features of democratic governments to contribute to implementation and compliance. Among such features, one can mention the following ones: a higher level of transparency, greater possibilities for interested citizens to establish nongovernmental organizations, to monitor government's activity, as well as to influence it (including using independent courts) ${ }^{42}$. Undoubtedly, in authoritarian states these possibilities are limited. Although it is difficult to distinguish states into completely democratic or completely authoritarian ones, some of them are more likely to belong to one of these two types. For example, the Byzantine state was rigidly centralized, the emperor was endowed with sacred features ${ }^{43}$. It is interesting

37 Draft Decision VI by the Meeting of the Parties to the Convention..., p. 1.

38 Ibid., p. 532.

39 Andrusevych, A. Ukraine's Compliance with Its Obligations..., p. 9-14.

40 Weiss, E.B., and Jacobson, H.K. A Framework for Analysis. In: Weiss, E.B., and Jacobson, H.K. (eds.). Engaging Countries: Strengthening Compliance with International Accords. 1998, p. 1-11.

41 Ibid.

42 Weiss, E.B., and Jacobson, H.K. A Framework for Analysis. In: Weiss, E.B., and Jacobson, H.K. (eds.). Engaging Countries: Strengthening Compliance with International Accords. 1998, p. 533. Ibid. 
in this regard that, as scientists claim, Ukraine took over the Byzantine culture ${ }^{44}$ and Russia has many characteristics of the Byzantine model ${ }^{45}$. A strong authority in the situation of developing civil society has more opportunities to realize its own goals and interests, calling them the goals and interests of the state, as well as to abuse the power. Obviously, in such a situation, the government "is not interested" in the opinion of citizens (which creates the preconditions for limiting public participation in public affairs). The situation with the opinion of other countries is the same, which affects the implementation of the Espoo Convention. Patriarchal society manifested at different levels of authority (on the state as well as on the family level) creates more prerequisites for the formation of an authoritarian state.

What is more, democracy is still young in Ukraine, as it became independent only with the collapse of the Soviet Union in 1991. In Ukraine, the concept of services rendered by the authority aimed at meeting society's needs ${ }^{46}$ is relatively new. Reforms are under way, but transparency of governmental decision making has not been established. Environmental rights are stated in the Constitution of Ukraine and in Ukrainian laws, but lack of institutional capacity and enforcement makes achieving these rights more difficult. Ukraine does not have long traditions and cultures of participatory democracy. The court system is not always independent and public officials may have no habit of dealing with issues related to the implementation of the Espoo Convention. In short, the ideals of transparent and participatory government are not yet part of the normal expectations of civil servants, leading to a greater likelihood of noncompliance than in countries with such expectations ${ }^{47}$.

Regarding the last important factor involving the country (its goals and interests), the following should be noted. Having analyzed the obstacles to implementation of and compliance with multilateral environmental agreements (MEAs) at the national level, the Fifth Ministerial Conference "Environment for Europe" mentioned the following obstacles: a lack of sufficient political attention to implementation; a lack of awareness of the obligations arising under the MEAs by the implementing authorities; a lack of technical, administrative and financial capacity; a lack of coordination among relevant national authorities; a lack of understanding of implementation issues; insufficient preparation (as regards, for example, laws, regulations, training); uncertain or inaccurate data; a lack or total absence of monitoring and/or review of implementation; unclear implementing rules/tools/regulations (for example, related to the translation and interpretation of legal terms and provisions); a failure

44 Wy wwazajete Ukrainu Ewropejskoju derzawoju? POSTUP. 2001, 148 (806) [interactive]. [accessed on 02-02-2014]. <http://postup.brama.com/010928/148_2_1.html>.

45 T.D., and, V.ARosija $i$ Wizantija: wozmoznosti i granicy crawnenija [interactive]. [accessed on 02-02-2014]. <http://library.mephi.ru/data/scientific-sessions/2003/6/108.html>.

46 Koncepcija administratywnoji reformy, zatwerdzena Ukazom Prezydenta Ukrainy, 22.07.1998. Uriadowyj kurjer. 1998, 141-142. 
to mobilize public support; insufficient budget allocations, changes in economic circumstances or unforeseen costs of implementation ${ }^{48}$.

Undoubtedly, all of these obstacles have a role in the increasing complexity of application of international agreements. Even more obviously, it is the political will that plays a crucial role in the final decision regarding the implementation of an international agreements. If it is acknowledged that the compliance is serving the state's interests, a wide range of measures can be implemented in order to assure the compliance. Then, the rest mentioned obstacles with a high level of probability will be overcome. Of course, the political will is not enough and the final result also depends on the capacity to implement the agreement. However, the implementation of the Espoo Convention does not require huge financial or human resources.

Political decision not to apply the Convention in the Bystroe Canal Case can be explained in the following way. Obviously, law in general (as well as international law in particular) can be enforced by imposing sanctions on non-abiding subjects. Regarding the case in question, the Meeting of the Parties to the Espoo Convention has already issued a caution to the Government of Ukraine. Issuing a caution is a sanction that works through the reputation effect ("name and shame"). However, recalling Maslow's hierarchy of needs, apparently, the "physiological or safety needs" (in this case - renovation of the canal) will take precedency of "the reputation" (a caution). In other words, it is a question of cost-benefit analysis. If the costs are too high and the added value is not attractive enough, what can be done to enforce anybody to do what should be done?

In the considered case, the costs are "to take due account of the outcome of the environmental impact assessment, including the environmental impact assessment documentation, as well as the outcome of the consultations with the Affected Party and the comments submitted by its citizens" in the final decision on the proposed activity. The benefits are "to have a caution no effective", to remain "a full member of the Espoo Convention", etc. Even though some authors tend to believe that the membership of the Espoo Convention brings a real advantage for Ukraine ${ }^{49}$, it is not easy to see the rationale behind their suggestion. Regrettably, the inherently soft character and rather political nature of the recommendations of the bodies established by international agreements are the conditions of signing these agreements by the parties $^{50}$.

48 Guidelines for Strengthening Compliance with and Implementation of Multilateral Environmental Agreements (MEAs) in the ECE Region. Adopted by the Fifth Ministerial Conference "Environment for Europe" on 21-23 May 2003 [interactive]. [accessed on 02-022014]. <http://www.unece.org/fileadmin/DAM/env/documents/2003/ece/cep/ece.cep.107. e.pdf>.

49 Marsden, S., and Koivurova, T. Transboundary Environmental Impact Assessment in the European Union: The Espoo Convention and Its Kiev Protocol on Strategic Environmental Assessment. Routledge, 2013, p. 287.

Horna, A.V. Procedural Aspects Concerning Jurisdiction and Admissibility in Cases of 


\section{Conclusions}

While the Espoo Convention is the important international document that stipulates transboundary environmental impact assessment, Ukraine fails to implement its provisions in an adequate way. This can be seen in the example of the Bystroe Canal Project, which was started to design more than 10 years ago and yet has not been adjusted in accordance with the Espoo Convention. Even though the Meeting of the Parties to the Espoo Convention issued a caution to become effective to the Government of Ukraine in order to urge it to comply with the relevant provisions of the Espoo Convention, Ukraine did not fulfill its obligations under the Convention. Namely, works regarding the Bystroe Canal Project authorized with the violations of the Espoo Convention were continued. In response to the request of the Meeting of the Parties to the Espoo Convention, Ukraine adopted a strategy on implementation of the Espoo Convention into Ukrainian legislation. However, recent changes in the legislation on the development control have not satisfied the strategy. Thus, the Ukrainian government was just imitating compliance with the Espoo Convention in order to try to avoid imposing sanctions. Unfortunately, even though the persistent noncompliance was quite obvious, due to inherently soft character and rather political nature of the recommendations of the Meeting of the Parties to the Espoo Convention, it is almost impossible to compel the party of the Convention to follow its provisions. Furthermore, the lack of political will to implement the Espoo Convention, insufficient level of democracy and economic problems faced by Ukraine complicate the situation even more. However, in this uneasy transitional situation efforts made by Ukrainian civil society as well as by the international community in order to bring Ukraine into compliance with universally recognized norms and standards are even more valuable.

\section{References}

Aarhus Convention on Access to Information, Public Participation in Decision Making and Access to Justice in Environmental Matters, June 25, 1998, 38 I.L.M. 517 (entered into force Oct. 30, 2001).

Alekseyeva, Y. Once again about the Aarhus Convention and Ukraine's
Failure to Comply with Its Obligation. Environment People Law Journal. 2011, 9-10(49-50): 9-12 [interactive]. [accessed on 02-02-2014]. <http://epl. org.ua/uploads/media/EPL_2011_ 09_10_web_01.pdf>.

Amendment of the Operating Rules of the Implementation Committee. Decision 
V/4 of the Meeting of the Parties on Review of Compliance, Doc. ECE/ MP.EIA/15, Annex. [interactive]. [accessed on 02-02-2014]. <http:// www.unece.org/fileadmin/DAM/ env/documents/2011/eia/decision. V.4.e.pdf>.

Andrusevych, A. Ukraine's Compliance with Its Obligations under the Convention on Access to Information, Public Participation in Decision Making and Access to Justice in Environmental Matters. Environment People Law Journal. 2006, 1(31): 9-14 [interactive]. [accessed on 02-02-2014]. <http://epl. org.ua/uploads/media/V31.pdf>.

Bastmeijer, K.; Koivurova, T. (eds.). Theory and Practice of Transboundary Environmental Impact Assessment. Boston: Brill/Martinus Nijhoff Publishers, 2008.

Boschiero, N.; Scovazzi, T.; Pitea, C.; Ragni, C. (eds.). International Courts and the Development of International Law: Essays in Honour of Tullio Treves. Springer, 2013.

Case EIA/IC/S/1 bis - Romania vs Ukraine [interactive]. [accessed on 02-02-2014]. $<$ http://www.unece.org/env/eia/imple mentation/eia_ic_s_1.html $>$.

Decision IV/2, Annex I, para. 55 [interactive]. [accessed on 02-02-2014]. <http://www.unece.org/fileadmin/ DAM/env/documents/2008/eia/ece. mp.eia.10.e.pdf $>$.

Draft Decision VI by the Meeting of the Parties to the Convention, para. 46 [interactive]. [accessed on 02-02-2014]. <http://www.unece.org/fileadmin/ DAM/env/documents/2014/EIA/MOP/ ECE.MP.EIA.2014.L.1.adcopy.pdf>.

ECE/MP.EIA/4, Decision II/4 [interactive]. [accessed on 02-02-2014]. <http://
www.unece.org/fileadmin/DAM/ env/documents/2001/eia/decision. II.4.e.pdf $>$.

Espoo Convention on Environmental Impact Assessment in a Transboundary Context, February 25, 1991 (entered into force Sep. 10, 1997).

Fauchald, O.K.; Hunter D.; Xi, W. (eds.). Yearbook of International Environmental Law. Volume 20, 2009. Oxford University Press, 2011.

Findings and Recommendations Further to a Submission by Romania Regarding Ukraine (EIA/IC/S/1) [interactive]. [accessed on 02-02-2014]. <http://www.unece.org/fileadmin/ DAM/env/documents/2008/eia/ece. mp.eia.2008.6.e.pdf>.

Foster, C.E. Science and the Precautionary Principle in International Courts and Tribunals: Expert Evidence, Burden of Proof and Finality. Cambridge University Press, 2011.

Guidelines for Strengthening Compliance with and Implementation ofMultilateral Environmental Agreements (MEAs) in the ECE Region. Adopted by the Fifth Ministerial Conference "Environment for Europe" on 21-23 May 2003 [interactive]. [accessed on 02-02-2014]. <http://www.unece.org/fileadmin/ DAM/env/documents/2003/ece/cep/ece. cep.107.e.pdf>.

Handl, G.; Zekoll, J.; Zumbansen, M. P. (eds.). Beyond Territoriality: Transnational Legal Authority in an Age of Globalization. Nijhoff Publishers, 2012.

Horna,A.V.ProceduralAspectsConcerning Jurisdiction and Admissibility in Cases of Maritime Delimitation before the ICJ. International Courts and the Development of International Law: 
Essays in Honour of Tullio Treves. Springer, 2013.

Introduction to Espoo Convention from the Convention's Website [interactive]. [accessed on 02-02-2014]. <http://www. unece.org/env/eia/welcome.html >.

Iwański, T. Ukraina - Rumunia: przedłużający się impas. Komentarze ośrodka studiów wschodnich im. Marka Karpia. 2011, 68 [interactive]. [accessed on 02-02-2014]. <http:// www.osw.waw.pl/sites/default/files/ komentarze_68.pdf $>$.

Jacobson, H.K.; Weiss, E.B. Assessing the Record and Designing Strategies to Engage Countries. In: Weiss, E.B.; Jacobson, H.K. (eds.). Engaging Countries: Strengthening Compliance with International Environmental Accords. MIT Press, 2000.

Jendrośka, J. Practice and Relevant Cases that Emerged in the Context of the Espoo Convention Implementation Committee. Non-Compliance Procedures and Mechanisms and the Effectiveness of International Environmental Agreements. The Hague: T. M. C.Asser Press, 2009, p. 328-331 [interactive]. [accessed on 02-02-2014]. <http://air.unimi.it/ bitstream/2434/57918/2/treves_240 109.pdf $>$.

Koncepcija administratywnoji reformy, zatwerdzena Ukazom Prezydenta Ukrainy, 22.07.1998. Uriadowyj kurjer. 1998, 141-142.

Konstytucija Ukrainy of 28.06.1996, № 254К/96-BP [interactive]. [accessed on 02-02-2014]. <http://zakon2.rada. gov.ua/laws/show/254\%D0\%BA/96$\% \mathrm{D} 0 \% \mathrm{~B} 2 \% \mathrm{D} 1 \% 80>$.

Kravchenko, S. Aarhus Convention and Innovations in Compliance with Multilateral Environmental Agreements. Colorado Journal of International Environmental Law and Policy. 2007, 1(18) [interactive]. [accessed on 02-02-2014]. <http:// papers.ssrn.com/sol3/papers.cfm?ab stract_id $=1076746>$.

Letter to Mr Nemyrya, Deputy Prime Minister of Ukraine, from Mr Kubis, Executive Secretary of UNECE [interactive]. [accessed on 02-022014]. <http://www.unece.org/ fileadmin/DAM/env/eia/documents/ ImplementationCommittee/eia.ic.s/ eia.ic.s.1/Letter_by_Mr_Kubis_to_ Mr_Nemyrya_20_Mar_09.pdf>.

Marsden, S.; Koivurova, T. Transboundary Environmental Impact Assessment in the European Union: The Espoo Convention and Its Kiev Protocol on Strategic Environmental Assessment. Routledge, 2013.

Melen', O. Kanal Dunaj-Chorne More - Nevyriseni Pytannia. Visnyk Ekologicnoji Advokatury. 2006, 30 [interactive]. [accessed on 02-022014]. <http://epl.org.ua/uploads/media/ V30.pdf $>$.

Melen', O. Dunajs'ka Sprava Tryvaje. Visnyk Ekologicnoji Advokatury. 2005, 28-29 [interactive]. [accessed on 0202-2014]. <http://epl.org.ua/uploads/ media/V28-29.pdf $>$.

Operating Rules of the Implementation Committee. Decision IV/2 of the Meeting of the Parties, Doc. ECE/ MP.EIA/10 [interactive]. [accessed on 02-02-2014]. <http://www.unece.org/ fileadmin/DAM/env/eia/documents/ Implementation Committee/IC_ operatingrules_en.pdf $>$. 
Progress reportbyUkraine of 29December 2011 is available at the Convention's website [interactive]. [accessed on 02-02-2014]. <http://www.unece.org/ fileadmin/DAM/env/eia/documents/ ImplementationCommittee/eia.ic.s/ eia.ic.s.1/Report_Ukraine_2011_eng_ correctAppendix2.pdf $>$.

Progress reportbyUkraine of 31 December 2012 is available at the Convention's website [interactive]. [accessed on 02-02-2014]. <http://www.unece.org/ fileadmin/DAM/env/eia/documents/ ImplementationCommittee/eia.ic.s/ eia.ic.s.1/Report_by_Ukraine_31.12. 2012_ENG.pdf>.

Report by the Meeting of the Parties at Its Fifth Session (ECE/MP.EIA/15), Decision V/4 [interactive]. [accessed on 02-02-2014]. <http://www. unece.org/fileadmin/DAM/env/ documents/2011/eia/decision.V.4.e. pdf>.

Report of the Compliance Committee of the Aarhus Convention on Its Seventh Meeting. Addendum, p. 3 [interactive]. [accessed on 0202-2014]. <http://www.unece.org/ fileadmin/DAM/env/pp/compliance/ S2004-01/S01C03findings.pdf $>$.

Report of the Fourth Meeting of the Parties (ECE/MP.EIA/10), para. 43 [interactive]. [accessed on 02-02-2014]. <http://www.unece.org/fileadmin/ DAM/env/documents/2008/eia/ece. mp.eia.10.e.pdf $>$.

Rio Declaration on Environment and Development. Report of the United Nations Conference on the Human Environment, Stockholm, 5-16 June 1972 (United Nations publication, Sales No. E.73.II.A.14 and corrigendum), chap. I [interactive]. [accessed on 02-02-2014]. <http:// www.un.org/documents/ga/conf151/ aconf15126-1annex1.htm>.

Schmeier, S. Governing International Watercourses: River Basin Organizations and the Sustainable Governance of Internationally Shared Rivers and Lakes. Routledge, 2012.

Shwed, T.D.; Makedonskaya, V.A. Rosija $i$ Wizantija: wozmoznosti $i$ granicy crawnenija [interactive]. [accessed on 02-02-2014]. <http://library.mephi. $\mathrm{ru} /$ data/scientific-sessions/2003/6/ 108.html>.

The letter to Ukraine, dated 7 September 2011, is available at the Convention's website [interactive]. [accessed on 02-02-2014]. <http://www.unece.org/ fileadmin/DAM/env/eia/documents/ ImplementationCommittee/eia.ic.s/ eia.ic.s.1/Letter_to_Ukraine_7.9.11. pdf $>$.

Weiss, E.B.; Jacobson, H.K. A Framework for Analysis. In: Weiss, E.B.; Jacobson, H.K. Engaging Countries: Strengthening Compliance with International Accords. 1998.

Wy wwazajete Ukrainu Ewropejskoju derzawoju? POSTUP. 2001, 148(806) [interactive]. [accessed on 0202-2014]. <http://postup.brama. com/010928/148_2_1.html >.

Zakon Ukrainy "Pro Ratyfikatsiju Konvencii pro Ocinku Vplyvu na Navkolysnie Seredovyscie u Transkordonnomu Konteksti” № 534-XIV of 19.03.1999. Vidomosti Verhovnoj Rady Ukrainy. 1999, № 34. 


\title{
TAM TIKROS ESPO KONVENCIJOS İGYVENDINIMO PROBLEMOS UKRAINOJE (BISTRAJOS KANALO PAVYZDYS)
}

\author{
Victoria Rachynska \\ Opolès universitetas, Lenkija
}

\begin{abstract}
Anotacija. Ukrainai nepavyksta imtis reikalingu teisiniu, administraciniu ir kitu priemoniu, kad bütu igyvendinta Jungtiniu Tautu poveikio aplinkai įvertinimo tarpvalstybiniame kontekste konvencija (Espo konvencija). Vienas iš tokiu Ukrainos nesèkmés pavyzdžiu laikantis Konvencijos yra Bistrajos kanalo projektas. Politinés valios stoka, nepakankamas demokratijos lygis ir ekonomines Ukrainos problemos laikytinos pagrindinèmis priežastimis, kodèl šio tarptautinio dokumento nèra laikomasi.
\end{abstract}

Reikšminiai žodžiai: poveikio aplinkai ịvertinimas, reikšmingas neigiamas tarpvalstybinis poveikis, Espo konvencija, Espo konvencijos igyvendinimo komitetas, Bistrajos kanalo byla.

\section{SELECTED PROBLEMS OF THE IMPLEMENTATION OF THE ESPOO CONVENTION IN UKRAINE (ON THE EXAMPLE OF THE BYSTROE CANAL CASE)}

\author{
Victoria Rachynska \\ Opole University, Poland
}

Summary. The Convention on Environmental Impact Assessment in a Transboundary Context (the Espoo Convention) stipulates that in case of authorizing a proposed activity that is likely to cause a significant adverse transboundary impact on the environment of a Party/ Parties of the Convention, the Party, under jurisdiction of which a proposed activity is planned, shall provide the affected Party/ Parties with an opportunity to participate in the authorization of this activity.

Even though the Convention was ratified by Ukraine as early as in 1999, it failed to undertake the necessary legal, administrative or other measures to implement its provisions. Ukraine is not the only state being in non-compliance with the Convention. However, it may be considered as one of the most persistent violators of its obligations pursuant to the Convention. In particular, in the example case study concerning the Bystroe Canal Project, Ukraine violated Article 2, paragraph 3; Article 3, paragraph 2, 5(a) and 8; Article 4, paragraph 2; Article 5; Article 6, paragraph 1 and 2 of the Espoo Convention, and it did not comply with the recommendations of the Meeting of the Parties of this Convention. Even though the Meeting of the Parties to the Espoo Convention issued a caution to become effective to the Government of Ukraine in order 
to urge it to comply with the relevant provisions of the Espoo Convention, Ukraine did not fulfill its obligations under the Convention. Namely, works regarding the Bystroe Canal Project authorized with the violations of the Espoo Convention were continued. In response to the request of the Meeting of the Parties to the Espoo Convention, Ukraine adopted a strategy on implementation of the Espoo Convention into Ukrainian legislation. However, recent changes in the legislation on the development control have not satisfied the strategy. Thus, the Ukrainian government was just imitating compliance with the Espoo Convention in order to try to avoid imposing sanctions. Unfortunately, even though the persistent noncompliance was quite obvious, due to inherently soft character and rather political nature of the recommendations of the Meeting of the Parties to the Espoo Convention, it is almost impossible to compel the party of the Convention to follow its provisions. Furthermore, the lack of political will to implement the Espoo Convention, insufficient level of democracy and economic problems faced by Ukraine complicate the situation even more. However, in this uneasy transitional situation efforts made by Ukrainian civil society as well as by the international community in order to bring Ukraine into compliance with universally recognized norms and standards are even more valuable.

Keywords: environment impact assessment, significant adverse transboundary impact, the Espoo Convention, the Implementation Committee of the Espoo Convention, the Bystroe Canal Case.

Victoria Rachynska, Kijevo Teisinių j̇žvalgų ir teisinės ekspertizès instituto doktorantė, Opolès universiteto (Lenkija) Teisès ir administravimo fakulteto stažuotoja. Mokslinių interesų sritys: aplinkosaugos teisė, poveikio aplinkai vertinimas, žmogaus teisès.

Victoria Rachynska, the Institute of Legislative Foresight and Legal Expertise (Kyiv), PhD student; Opole University (Poland), Faculty of Law and Administration, intern. Research interests: environmental law, environment impact assessment, human rights law. 